\title{
Flourishing in nature: A review of the benefits of connecting with nature and its application as a wellbeing intervention
}

\author{
Colin A. Capaldi · Holli-Anne Passmore - Elizabeth K. Nisbet • John M. Zelenski • \\ Raelyne L. Dopko
}

\begin{abstract}
From the increasing number of people living in urban areas to the continued degradation of the natural environment, many of us appear to be physically and psychologically disconnected from nature. We consider the theoretical explanations and present evidence for why this state of affairs might result in suboptimal levels of hedonic and eudaimonic wellbeing by review ing the large body of research on the mental health benefits of connecting with nature. The advantages of contact with nature as a potential wellbeing intervention are discussed, and examples of how this research is being applied to reconnect individuals to nature and improve wellbeing are given. We conclude by considering the limitations of, and proposing future directions for, research in this area. Overall, evidence suggests that connecting with nature is one path to flourishing in life.
\end{abstract}

Keywords: nature, nature connectedness, flourishing, subjective wellbeing, hedonic wellbeing, eudaimonic wellbeing, human-nature

\section{Introduction}

From ancient Chinese healers to Western writers such as Henry David Thoreau, the belief that connecting with the natural world improves wellbeing repeatedly appears throughout recorded hum an history (Selhub \& Logan, 2012). Despite the durability of this belief over time and across cultures, numerous trends suggest that many are ignoring this time-tested wisdom, and are disconnected, both physically and psychologically, from nature. ${ }^{1}$ Since 1950 , the percentage of the world's population living in a relatively nature-impoverished urban milieu, versus the nature-rich surroundings of rural life, has almost doubled from $30 \%$ to $54 \%$, and is as high as $82 \%$ in North America (United Nations, 2014). The shift to urban living is expected to continue and become even more pronounced as the twenty-first century progresses. In financially wealthy, industrialized nations, less than $10 \%$ of each day, on average, is spent outdoors (Evans

\footnotetext{
${ }^{1}$ For the purpose of this article, our conceptualization of "nature" is similar to the definition outlined in Hartig, Mitchell, de Vries, \& Frumkin (2014). Specifically, we de fine nature broadly as environments and physical fe atures of nonhuman origins, ranging from plants to non-built landscapes. This conceptualization corresponds well with how nature is commonly ope rationalize d by researchers; it is also in line with lay conce ptions of what constitutes nature (Vining, Merrick, \& Price, 2008; cf. Descola \& Pálsson, 1996). We belie ve that this conceptualization offers a representative vie w of the lite ra ture on this topic, yet includes variation that might be parsed more precisely in future work. It is important to note that nonhuman animals fall under the umbrella of some conceptualizations of nature, but will not be focused on in this review (see Amiot \& Bastian, 2014 instead).
} 
\& McCoy, 1998; MacKerron \& Mourato, 2013; Matz et al., 2014) and per capita participation in nature-based recreation is declining (Pergams \& Zaradic, 2008). Children are spending less time outdoors (Louv, 2005), opting for large amounts of screen time instead (Rideout, Foehr, \& Roberts, 2010). Emblematic of the modern popularity of electronic media over nature-based recreation (Pergams \& Zaradic, 2006), children seem to be better at identifying Pokémon than common wildlife species (Balmford, Clegg, Coulson, \& Taylor, 2002). Simultaneously, the necessary behavior change required to address and mitigate environmental issues such as climate change remains largely unactualized, and the health of the natural environment continues to deteriorate due to human (in)action (Intergovernmental Panel on Climate Change, 2014). In sum, many people are not as connected to nature as they could be and this has implications, not only for the wellbeing of the environment, but also for the wellbeing of individuals. In fact, there is growing evidence that supports the age-old belief that connecting with nature promotes flourishing (i.e., enhanced hedonic and eudaimonic wellbeing) and positive mental health. Without regular contact with nature, however, people may be missing out on some of these psychological benefits.

We examine two related, but distinct, aspects of the human-nature experience-nature contact and nature connectedness - and how they relate to and promote flourishing. Nature contact involves interacting with the natural world, such as being immersed in a natural environment, being around natural elements indoors (e.g., plants), or being exposed to virtual representations of nature (e.g., viewing photographs or videos of natural landscapes). Contact with nature can be relatively brief, intermittent, or regular. Nature connectedness, however, refers to one's subjective sense of connection with the natural world. Although typically conceived of as an individual difference (see Tam, 2013), nature connectedness can also be measured as a state; it can fluctuate in the short-term depending on situational context. Individuals who are more connected to nature spend more time outdoors (Mayer \& Frantz, 2004; Nisbet, Zelenski, \& Murphy, 2009; Tam, 2013), and nature contact often increases momentary feelings of connectedness (Mayer, Frantz, Bruehlman-Senecal, \& Dolliver, 2009; Nisbet, 2013, 2014; Nisbet \& Zelenski, 2011). In this review, we also discuss the advantages of contact with nature as a potential wellbeing intervention, and how research from this area is being applied to connect individuals with nature to improve wellbeing. We then consider the gaps in the literature, and outline future research directions and implications.

\section{Why is nature ben eficial to w ellbeing? Theoretical explanations}

Three major theories address the question of why connecting with nature is beneficial to our wellbeing: biophilia, attention restoration, and stress reduction. The biophilia hypothesis posits that our ancestors' wellbeing and survival depended on connecting with nature (i.e., for finding food and water, navigating, and predicting time or future weather conditions, etc.; Kellert \& Wilson, 1993). Humans have begun living in urban environments only recently (Wilson, 1984); therefore, the need to connect with nature likely remains an innate part of who we are. Although evolutionary concepts like biophilia are difficult to test, suggestive evidence comes from studies that find preferences for nature scenes over built environments (Dopko, Zelenski, \& Nisbet, 2014; Hartig, Böök, Garvill, Olsson, \& Gärling, 1996; Kaplan \& Kaplan, 1989; Kaplan, Kaplan, \& Wendt, 1972; Ulrich, 1981; Van den Berg, Koole, \& van der Wulp, 2003), and attraction to nature being evidenced across diverse cultures (e.g., Ulrich, 1993; Newell, 1997) and at very young ages (e.g., Kahn, 1997). A multitude of studies, discussed below, also suggest that satisfying our need to connect with nature boosts wellbeing. 
Attention restoration theory (Kaplan \& Kaplan, 1989) provides another explanation for nature's beneficial effects. ${ }^{2}$ This theory distinguishes between directed attention (which is used for executive functions and involves prolonged focus and effort) and involuntary attention (which is effortless yet demanding). Directed attention is a limited resource that becomes fatigued after extended use and, when depleted, may lead to negative emotional states (e.g., irritability) and declines in cognitive performance. Natural environments seem particularly restorative: they provide an opportunity to get away, contain fascinating rich stimuli that effortlessly engage our involuntary attention, and allow us to act without the need to constantly monitor our behavior (Kaplan \& Kaplan, 1989). Numerous empirical studies report improvements in concentration, directed attention (Berman, Jonides, \& Kaplan, 2008; Berto, 2005; Hartig, Evans, Jamner, Davis, \& Gärling, 2003; Van den Berg et al., 2003), and emotional functioning (discussed below) after contact with nature.

Finally, stress-reduction theory (Ulrich et al., 1991) maintains that exposure to certain (unthreatening) natural environments that were evolutionarily beneficial for wellbeing and survival automatically elicits a variety of stress-reducing psychophysiological responses. Compared to built environments, nature can decrease arousal and perceived stress levels (Ulrich, 1979, 1981; Ulrich et al., 1991), and promote psychophysiological stress recovery (e.g., decrease blood pressure) after attentional abilities are fatigued (Hartig et al., 2003). Moreover, access to nearby nature can buffer against stress (Stigsdotter et al., 2010; Van Herzele \& de Vries, 2012; Van den Berg, Maas, Verheij, \& Groenewegen, 2010; Ulrich, 1981). Researchers in Japan have tested how specific elements of nature, such as wood or the sound of running water, influence the human stress response. Several decades of evidence suggests that contact with nature can lower pulse rates, reduce cortisol levels, and improve immune functioning (Tsunetsugu, Park, \& Miyazaki, 2010; cf. Bowler, Buyung-Ali, Knight, \& Pullin, 2010).

Beyond the idiosyncrasies of each theory, their implications are similar: connecting with nature should support human wellbeing and functioning. Next, we provide a comprehensive review of the empirical research that has tested this hypothesis.

\section{Nature and hedonic wellbeing}

Researchers have investigated the short- and long-term effects of contact with nature on hedonic wellbeing, and the association between hedonic wellbeing and nature connectedness. Hedonic wellbeing, which is also referred to as subjective or emotional wellbeing, consists of high levels of positive emotions, low levels of negative emotions, and a sense of satisfaction with one's life (Diener, 2009; Keyes, 2002). In essence, hedonic wellbeing is the feeling good component of wellbeing (Keyes \& Annas, 2009).

Numerous studies have shown that brief contact with nature promotes positive emotional states. For instance, relatively brief walks in natural, versus urban/indoor, environments can lead to significant boosts in mood (Mayer et al., 2009; Nisbet \& Zelenski, 2011), even for those diagnosed with mood disorders (Berman et al., 2012). A recent meta-analysis of 32 randomized controlled studies with over 2,000 participants corroborates this; contact with nature results in moderate, significant increases in positive affect, as well as small, but significant, decreases in negative affect (McMahan \& Estes, 2015). Similar findings are reported in other systematic

\footnotetext{
${ }^{2}$ More recently, Stephen and Rachel Ka plan have de veloped a broa der framework called the reasonable person model that focuses on how environmental factors can influence cognition, behaviour, and wellbeing by supporting human informational needs (see Kaplan, 2000; Kaplan \& Basu, 2015; Kaplan \& Kaplan, 2003, 2009). Although it is not as commonly cited in the nature-wellbeing literature as the other three theories, the reasonable person model can also help explain nature's wide-ranging beneficial effects on human flourishing.
} 
reviews on the health benefits of nature (Bowler et al., 2010) and the effect of "green exercise" on mental wellbeing (Thompson-Coon et al., 2011). Additional support comes from an experience sampling study of 20,000 residents of the United Kingdom (MacKerron \& Mourato, 2013). Even after controlling for a variety of confounding variables (e.g., weather, social company, type of activity, day of the week), people were happier when in natural environments than when in urban ones.

Technologically mediated or virtual exposure to nature (e.g., viewing images or videos) is also generally associated with enhanced hedonic wellbeing (see Velarde, Fry, \& Tviet, 2007). When virtual exposure to nature is com pared to actual contact with nature, however, real nature experiences provide a greater mood boost (Kahn, Severson, \& Ruckert, 2009; Mayer et al., 2009; McMahan \& Estes, 2015). Thus, while browsing nature photographs or watching a nature documentary is likely to improve mood, getting outdoors and connecting directly with nature may be optimal for maximizing happiness.

Given the positive hedonic outcomes, one may question why people are not spending time in nature (Evans \& McCoy, 1998; MacKerron \& Mourato,2013; Matz et al., 2014). One explanation for this disconnect is that nature's effects on wellbeing are underappreciated. Although people often overestimate the impact of emotional experiences (i.e., people make affective forecasting errors; Wilson \& Gilbert, 2005), the reverse may be true for contact with nature. In experiments testing anticipated and actual experiences, Nisbet and Zelenski (2011) found that, on average, people tend to underestimate the mood benefits of brief contact with nature. This prediction error maybeleading people to choose less healthy activities, resulting in missed opportunities to foster positive mental health and a greater connectedness with nature.

Relatively less attention has been given to examining the longer-term effects of nature exposure on hedonic wellbeing. There is, however, some evidence that repeated contact with nature leads to improved emotional functioning and greater life satisfaction. A survey of 3,000 Finnish participants found that those who reported spending more of their leisure time engaged in nature-based recreational activities had higher emotional wellbeing than those who reported spending less of their free time in nature (Korpela, Borodulin, Neuvonen, Paronen, \& Tyrväinen, 2014). A series of large-scale European studies based on data from national surveys has investigated the influence of nearby green space on wellbeing and mental health (de Vries, Verheij, Groenewegen, \& Spreeuwenberg, 2003; Maas et al., 2009; Van den Berg et al., 2010; White, Alcock, Wheeler, \& Depledge, 2013). These studies consistently find that living in an area with more green space is associated with less mental distress than living in an area with less green space. Moreover, in a longitudinal study that had over 10,000 U.K. residents (White et al., 2013), living in a greener urb an area was associated with greater life satisfaction. Thus, it appears that having access to nature near one's home can provide a buffer against mental distress and promote a sense of satisfaction with one's life (cf. Huynh, Craig, Janssen, \& Pickett, 2013 for an exception).

Studies that ask participants to connect with nature have found similar results. For example, after a two-week intervention, participants randomly assigned to increase their time in nature reported higher net-positive affect compared to participants in a control condition (Passmore \& Howell, 2014). Similar improvements were reported by Canadians participating in the David Suzuki Foundation's month-long 30x30 nature challenge (Nisbet, 2013, 2014), which is described in more detail below. Richardson, Hallam, and Lumber (2015) had participants write about three good things they had noticed in nature for a five-day period. Positive feelings elicited by nature was one of the common themes identified in the writings. Overall, these studies support the notion that repeatedly connecting with nature is associated with enhanced hedonic wellbeing. 
Beyond contact with nature, trait connectedness with nature is also associated with increased hedonic wellbeing. A recent meta-analysis of 30 samples containing over 8,500 participants found a significant relationship between nature connectedness and happiness indicators such as positive affect and life satisfaction (Capaldi, Dopko, \& Zelenski, 2014). Connectedness may motivate people to seek nature contact, due to the reinforcing mental health benefits these experiences provide. Nature connectedness has also been linked with psychological resilience, which is key in managing stress and maintaining positive mental health (Ingulli \& Lindbloom, 2013). In sum, a plethora of research shows that connecting with nature is associated with improved emotional functioning and satisfaction with life.

\section{Nature and eudaimonic wellbeing}

Although more research has focused on the link between nature and hedonia, some work has also explored nature's influence on broader aspects of wellbeing. Often loosely gathered under the term "eudaimonia", constructs such as meaning, autonomy, vitality, and feelings of transcendence represent additional components of mental health beyond merely feeling good. Eudaimonia has been described as the functioning well component of wellbeing (Keyes \& Annas, 2009).

Contact with nature and nature relatedness has been linked with several indicators of eudaimonic wellbeing. For example, feeling that one's life is meaningful correlates positively with nature connectedness (e.g., Cervinka, Roderer, \& Hefler, 2012; Nisbet, Zelenski, \& Murphy, 2011). Furthermore, experiences in natural environments are an im portant source of meaning for adults of all ages (Fegg, Kramer, L'hoste, \& Borasio, 2008; O'Connor \& Chamberlain, 1996; Reker \& Woo, 2011; Schnell, 2009; Steger et al., 2013), including clinical populations (e.g., Berger \& McLeod, 2006; Granerud \& Eriksson, 2014).

Empirical evidence links exposure to nature with increased autonomy, the ability to freely choose one's actions - an important part of eudaim onic wellbeing. In experimental research, the more immersed participants were in nature photographs, the more autonomous they felt (Weinstein, Przybylski, \& Ryan, 2009). Experiences in nature also appear to provide the freedom to be one's authentic self. Mayer et al. (2009) found that participants who were randomly assigned to take a walk in nature reported significantly reduced public self-awareness. In qualitative research, adults who had spent time in the wilderness reported that what made their experiences especially meaningful was the fact that "there was virtually no reason to be anyone but themselves" (Fredrickson \& Anderson, 1999, p. 30). Research from the outdoor education and experiential learning literature describes similar benefits of wilderness and nature immersion experiences on autonomy and other measures of psychological wellbeing like personal growth, self-esteem, self-regulation, and social competency (e.g., Norton \& Watt, 2014; Passarelli, Hall, \& Anderson, 2010; Ray \& Jakubec, 2014).

The experience of vitality - fully feeling alive and energized (Ryan \& Frederick, 1997) appears to be enhanced by connecting with nature. When research participants tracked their daily activities, greater vitality was associated with activities involving nature, regardless of physical exercise and social companionship levels (Ryan et al., 2010). An increase in vitality was even reported by participants who merely imagined themselves in an outdoor setting. In experimental studies, participants randomly assigned to walk in nature reported greater vitality than those who walked indoors (Nisbet \& Zelenski, 2011; Ryan et al., 2010). Finally, meta-analytic results show that those with a stronger connection with nature than others tend to report a greater sense of vitality (Capaldi et al., 2014). 
The elevating feelings of awe and inspiration, connection to a greater whole, and spiritual exaltation - the transcendent aspects of eudaimonic wellbeing - have been linked with nature as well. The sights and sounds of nature are some of the most common elicitors of awe (Keltner \& Haidt, 2003; Shiota, Keltner, \& Mossman, 2007; Terhaar, 2009), particularly fractal patterns found in trees, clouds, rain, and birdsongs (Forsythe \& Sheehy, 2011; Richards, 2001). Indeed, panoramic photographs of nature have been described as the "prototypical awe elicitor" (Shiota et al., 2007, p. 951), and even mundane images of nature can lead to increased feelings of awe (Joye \& Bolderdijk, 2014). Briefly viewing either unspectacular or awesome photographs of nature can make people feel more connected to others, more caring, and more spiritual (Joye \& Bolderdijk, 2014). Several other studies provide empirical support for a close relationship between spirituality and nature (Diessner, Solom, Frost, Parsons, \& Davidson, 2008; Leary, Tipsord, \& Tate, 2008; Saraglou, Buxant, \& Tilquin, 2008; Vining et al., 2008). Even imagined experiences in nature can evoke intense feelings of awe and connectedness, as well as the feeling of being in the presence of something greater than oneself (Shiota et al., 2007).

Thus far, we have primarily focused on the individual benefits of connecting with nature. However, just as conceptions of flourishing and mental health are incomplete without considering the social context (Keyes, 1998; World Health Organization, 2006), so is a discussion of nature's benefits without considering social aspects of wellbeing. Research shows that the amount of neighborhood green space is correlated with stronger social ties reported among neighbors and greater prosocial activity in the neighborhood (Kuo, 2003; Kuo, Sullivan, Coley, \& Brunson, 1998; Sommer, 2003; Sullivan, Kuo, \& Depooter, 2004). The prosocial effect of exposure to nature has also been demonstrated in experimental studies using videos or photographs (Joye \& Bolderdijk, 2014; Zelenski, Dopko, \& Capaldi, 2015), a plant-filled room (Weinstein et al., 2009), or after immersion in a forested urban park (Guéguen \& Stefan, 2014). The widespread social norm of giving flowers to others is also suggestive of nature's ability to foster positive relations. Indeed, evidence from experimental studies demonstrates that participants primed with flowers are more likely to help strangers (Guéguen, Meineri, \& Stefan, 2012), give money to others (Raihani \& Bshary, 2012; Stefan \& Guéguen, 2014; Stillman \& Hensley, 1980), act gregariously (Haviland-Jones, Rosario, Wilson, \& McGuire, 2005), and feel attracted to someone they have just met (Guéguen, 2011, 2012). Trait nature connectedness is positively associated with humanitarianism (Nisbet et al., 2009), social wellbeing (Howell, Dopko, Passmore, \& Buro, 2011; Howell, Passmore, \& Buro, 2013), kindness (Leary et al., 2008), empathic concern (Zhang, Piff, Iyer, Koleva, \& Keltner, 2014), altruistic concern (Schultz, 2001), and perspective taking (Schultz, 2001).

\section{Con tact with nature as a wellbeing intervention}

Despite the abundance of research demonstrating the beneficial effects that nature has on our cognitive, emotional, spiritual, and physical wellbeing, nature-based interventions are understudied and underutilized as a mental health strategy. This is surprising, given that research suggests interventions connecting people with nature could bring a plethora of positive changes across multiple domains of functioning. Furthermore, the effect of contact with nature on wellbeing does not appear to depend on trait connectedness (e.g., Passmore \& Howell, 2014) or gender (e.g., McMahan \& Estes, 2015). Willingness and adherence appear to be other advantages of this type of intervention; individuals who participate in nature-based interventions report high levels of intrinsic motivation and spend a considerable amount of time 
in nature (Nisbet, 2013, 2014; Passmore \& Howell, 2014). ${ }^{3}$ Additionally, connecting with nature is a relatively easy and likely cost-effective intervention. In the majority of the research reviewed, participants were exposed to ordinary, everyday natural environments accessible to most people. Those with limited access to nearby nature could benefit (albeit to a lesser extent) from viewing photographs or videos of nature. Existing research also suggests that the wellbeing boosts from nature contact can be achieved fairly quickly. Finally, preliminary evidence suggests that repeated contact with nature produces larger increases in wellbeing than other interventions commonly cited in the positive psychology literature (Passmore \& Howell, 2014). Although some therapists are incorporating nature into their practice (e.g., Berger \& McLeod, 2006; Burns, 1998; Buzzell \& Chalquist, 2009; Hasbach, 2012), relatively few programs or interventions appear to be capitalizing on nature as a positive mental health strategy. Nevertheless, somenotable exceptions are described below.

\section{Contact with nature interventions}

One of the largest programs under empirical study is the David Suzuki Foundation's 30x30 Nature Challenge. This campaign, which began in 2012, is an annual month-long intervention encouraging Canadians to spend 30 minutes per day in nature during the month of May. In general, participants double their weekly contact with nature, and report significant reductions in stress, and significant improvements in mood and vitality (Nisbet, 2013, 2014). Trait nature connectedness also increases significantly after the intervention, such that the greater the changes in connectedness, the greater the improvements in wellbeing.

Another notable nature-based intervention is the Canadian Mental Health Association's Mood Walks initiative. Aimed at promoting physical activity, mental health, and social connection, Mood Walks trains mental health organizations across Ontario and supports them in launching nature hike programs for older adults dealing with serious mental illnesses. Partnering with Conservation Ontario and Hike Ontario, over 20 mental health agencies participated in 2014. Preliminary results echo those found in the literature, with participants reporting significantly greater happiness and energy levels, as well as decreased anxiety, following the walks (Mood Walks, 2015). Mental health, in general, also improved significantly pre- to post-intervention.

Recognizing the importance of connecting children with nature, Forest and Nature Schools (FNS) have become increasingly popular in many countries around the world (McClean, 2015). In contrast to the conventional model of childhood education that takes place almost exclusively indoors, children in FNS spend much of their school day immersed in nature. The philosophy behind this approach tends to emphasize, in addition to regular nature contact, child-directed, inquiry- and play-based learning where the educator acts more as a facilitator than an authoritative teacher (Forest School Canada, 2014). While this approach to education has just recently caught on in North America, there are already hundreds of FNS operating in Europe (Westwood, 2013). Importantly, research suggests that FNS can have a positive influence on children across multiple domains of functioning (e.g., O'Brien \& Murray, 2007). ${ }^{4}$

Some political leaders are actively trying to encourage greater nature contact among their citizens. For instance, the then Canadian Prime Minister Stephen Harper announced that almost \$10 million would be allocated to connect urban Canadians to nature (CBC News, 2014) and

\footnotetext{
${ }^{3}$ Caution should be taken when interpreting Nisbet $(2013,2014)$ howe ver, as only self-selected individuals participated in the 30x30 Nature Challenge. Nevertheless, the participation of thousands of individuals without any incentive arguably supports the notion of intrinsic motivation.

${ }^{4}$ See Gill (2014) for a revie w of the benefits of nature contact for children.
} 
President Barack Obama is offering fourth grade students and their families free admission to national parks for a year as part of his Every Kid in a Park initiative (The White House, Office of the Press Secretary, 2015). As the evidence and public awareness of nature's benefits grow, the use of nature-based interventions will likely continue to expand. There are, however, some important caveats, areas for improvement, and unanswered questions in this research area that deserve mention.

\section{Moving for ward in nature}

The research and theory reviewed here provide reasons to be optimistic about the salubrious effects of nature contact and nature connectedness. Nonetheless, some difficult questions and important research gaps remain. Researchers in this area generally use pleasant nature as stimuli and neglect some of the more unpleasant aspects that may not be beneficial to human wellbeing (e.g., mosquitoes or forest fires). With so many possible operationalizations, researchers must be cautious with making broad conclusions about nature when testing only a few aspects of it. In experimental studies, appropriate control conditions need to be selected: a task made difficult without widely accepted or explicitly stated definitions of nature itself. Some research has already suggested that particularly beautiful, awesome, or immersive nature experiences provide additional benefits over more mundane nature stimuli (Joye \& Bolderdijk, 2014; Weinstein et al., 2009; Zhang et al., 2014), though other work does not seem to rely on using particularly extraordinary exemplars of nature. Beyond obviously phobic natural stimuli (e.g., snakes), untamed wilderness may generate anxiety or thoughts of death, at least for some (Koole \& Van den Berg, 2005). Nevertheless, a recent meta-analysis found that tamed vs. untamed nature did not moderate the effect of exposure to nature on positive emotions (McMahan \& Estes, 2015), and Hinds and Sparks (2011) noted that normally "negative" emotions of loneliness, isolation, and anxiety appear to be experienced more positively in natural environments. In general, this is an area ripe for future research. Such research might better define the particular kinds of nature that are most beneficial (e.g., water vs. forests; White et al., 2010), examine lowlevel visual features of nature (e.g., hue diversity; Berman et al., 2014), or vary the medium (video vs. actual) or sensory channel (sounds vs. images) of exposure to nature. There is also much to learn about moderators at the level of individual differences and immediate context.

Similar issues emerge when it comes to using nature or representations of nature as part of interventions designed to boost wellbeing. What kind of nature will work best? What is the ideal dose? How long do the effects last? Will optimal results require a good fit among the particular intervention method, the kind of nature, and the personal characteristics of the target (cf., Lyubomirsky \& Layous, 2013)? Attention should also be directed towards defining appropriate control groups when testing interventions. Much stronger support for the theoretical links between nature and wellbeing will be provided by intervention studies that have strong, active control groups, perhaps even comparing nature interventions to other established methods (e.g., positive psychology exercises). To date, most nature intervention research has not met the gold standard of broad sampling, random assignment, strong control groups, and longitudinal data collection. With generally promising results accumulating, we hope these more rigorous tests will happen soon.

Our review has focused on encouraging results, and these are largely what are found in the published literature. However, psychology, like other scientific fields, is increasingly concerned about publication bias and false positives. File drawers are likely filled with less supportive findings, and we suspect few researchers are actively working to contradict claims about nature's benefits. Nonetheless, there are reasons to remain optimistic. For example, publication status 
does not moderate the relationship between nature connectedness and subjective wellbeing (Capaldi et al., 2014). Additionally, researchers sometimes find unexpected beneficial effects of nature (e.g., when exposure to videos of natural environments was used as a control condition, in comparison to cognitive training; Borness, Proudfoot, Crawford, \& Valenzuela, 2013). Nevertheless, future meta-analyses should employ newer techniques that estimate and correct for publication bias (e.g., Simonsohn, Nelson, \& Simmons, 2014). The strongest evidence for nature's benefits-like other claims in psychological science-will require research that is transparent and has strong pre-registered methods.

Nature is certainly not a cure for every ailment and mental health issue. Even so, the evidence suggests that exposure to nature is a health and wellbeing promotion strategy that is underutilized (and perhaps unknown) by mental healthcare providers. Many people have access to some form of urban park, if not community garden, conservation area, or nature in their backyard. For the poorest and most vulnerable members of society, nature interventions may offer opportunities to enhance mood, reduce stress, and promote wellbeing, at relatively low cost. Overall, evidence suggests that connecting with nature is a promising path to flourishing in life.

\section{Authors}

Colin A. Capaldi

Carleton University

colin_capaldi@carleton.ca

Holli-Anne Passmore

University of British Columbia

Elizabeth K. Nisbet

Trent University

John M. Zelenski

Carleton University

Raelyne L. Dopko

Carleton University

Publishing Timeline

Received 7 July 2015

Accepted 28 October 2015

Published 18 December 2015

\section{References}

Amiot, C. E., \& Bastian, B. (2014). Tow ard a psychology of human-animal relations. Psychological Bulletin, 141, 6-47.http://dx.doi.org/10.1037/a0038147

Balmford, A., Clegg, L., Coulson, T., \& Taylor, J. (2002). Why conservationists should heed Pokémon. Science, 295, 2367.http://dx.doi.org/10.1126/science.295.5564.2367b

Berger, R., \& McLeod, J. (2006). Incorporating nature into therapy: A framew ork for practice. Journal of Systemic Therapies, 25, 80-94.http://dx.doi.org/10.1521/jsyt.2006.25.2.80

Berman, M. G., Hout, M. C., Kardan, O., Hunter, M. R., Yourganov, G., Henderson, J. M., ... Jonides, J. (2014). The perception of naturalness correlates $w$ ith low -level visual features of environmental scenes. PLoS ONE, 9(12), e114572.http://dx.doi.org/10.1371/journal.pone.0114572 
Berman, M. G., Jonides, J., \& Kaplan, S. (2008). The cognitive benefits of interacting with nature. Psychological Science, 19, 1207-1212.http://dx.doi.org/10.1111/j.1467-9280.2008.02225.x

Berman, M. G., Kross, E., Krpan, K. M., Askren, M. K., Burson, A., Deldin, P. J., ... Jonides, J. (2012). Interacting with nature improves cognition and affect for individuals with depression. Journal of Affective Disorders, 140, 300-305. http://dx.doi.org/10.1016/j.jad.2012.03.012

Berto, R. (2005). Exposure to restorative environments helps restore attentional capacity. Journal of Environmental Psychology, 25, 249-259.http://dx.doi.org/10.1016/j.jenvp.2005.07.001

Borness, C., Proudfoot, J., Crawford, J., \& Valenzuela, M. (2013). Putting brain training to the test in the w orkplace: A randomized, blinded, multisite, active-controlled trial. PLOS ONE, 8(3). http://dx.doi.org/10.1371/journal.pone.0059982

Bowler, D. E., Buyung-Ali, L. M., Knight, T. M., \& Pullin, A. S. (2010). A systematic review of evidence for the added benefits to health of exposure to natural environments. BMC Public Health, 10, 456. http://dx.doi.org/10.1186/1471-2458-10-456

Burns, G. W. (1998). Nature-guided therapy: Brief integrative strategies for health and wellbeing. Philadelphia, PA: Brunner/Mazel.

Buzzell, L., \& Chalquist, C. (2009). Ecotherapy: Healing with nature in mind. San Francisco, CA: Sierra Club Books.

Capaldi, C. A., Dopko, R. L., \& Zelenski, J. M. (2014). The relationship between nature connectedness and happiness: A meta-analysis. Frontiers in Psychology, 5, 976. http://dx.doi.org/10.3389/fpsyg.2014.00976

CBC News (2014, May 15). Stephen Harper reveals new National Conservation Plan. http://www.cbc.ca/news/canada/new-brunswick/stephen-harper-reveals-newnational-conservation-plan-1.2644274

Cervinka, R., Roderer, K., \& Hefler, E. (2012). Are nature lovers happy? On various indicators of wellbeing and connectedness with nature. Journal of Health Psychology, 17, 379-388. http://dx.doi.org/10.1177/1359105311416873

de Vries, S., Verheij, R. A., Groenew egen, P. P., \& Spreeuwenberg, P. (2003). Natural environments healthy environments? An exploratory analy sis of the relationship betw een greenspace and health. Environment and Planning A, 35, 1717-1731. http://dx.doi.org/10.1068/a35111

Descola, P., \& Pálsson, G. (1996). Introduction. In P. Descola and G. Pálsson (Eds.), Nature and society: Anthropological perspectives (pp. 1-21). London: Routledge.

Diener, E. (2009). Subjective well-being. In E. Diener (Ed.), The science of well-being: The collected works of Ed Diener (Vol. 37, pp. 11-58). New York, NY: Springer.

Diessner, R., Solom, R. C., Frost, N. E., Parsons, L., \& Davidson, J. (2008). Engagement with beauty: Appreciating natural, artistic, and moral beauty. Journal of Psychology, 142, 303-329. http://dx.doi.org/10.3200/JRLP.142.3.303-332

Dopko, R. L., Zelenski, J. M., \& Nisbet, E. K. (2014). Nature salience increases judgments of environmental satisfaction. Ecopsychology, 6, 207-217.http://dx.doi.org/10.1089/eco.2014.0042

Evans, G. W., \& McCoy, J. M. (1998). When buildings don't work: The role of architecture in human health. Journal of Environmental Psychology, 18, 85-94.http://dx.doi.org/10.1006/jevp.1998.0089

Fegg, M. J., Kramer, M., L'hoste, S., \& Borasio, G. D. (2008). The Schedule for Meaning in Life Evaluation (SMiLE): Validation of a new instrument for meaning-in-life research. Journal of Pain and Symptom Management, 35, 356-364. http://dx.doi.org/10.1016/j.jpainsymman.2007.05.007

Forest School Canada (2014). Forest and Nature School in Canada: A head, heart, hands approach to outdoor learning. http://www.forestschoolcanada.ca/wp-content/themes/wlf/images/FSC-Guide web.pdf

Forsythe, N., \& Sheehy, A. (2011). Is it not beautiful? The Psychologist, 24, 504-507.

Fredrickson, L. M., \& Anderson, D. H. (1999). A qualitativeexploration of the wilderness experience as a source of spiritual inspiration. Journal of Environmental Psychology, 19, 21-39.

$\underline{\text { http://dx.doi.org/10.1006/jevp.1998.0110 }}$

Gill, T. (2014). The benefits of children's engagement with nature: A systematic literature review. Children, Youth and Environments, 24, 10-34.http://dx.doi.org/10.7721/chilyoutenvi.24.2.0010 
Granerud, A., \& Eriksson, B. G. (2014). Mental health problems, recovery, and the impact of green care services: A qualitative, participant-focused approach. Occupational Therapy in Mental Health, 30, 317336. http://dx.doi.org/10.1080/0164212X.2014.938558

Guéguen, N. (2011). "Say it with flow ers": The effect of flowers on mating attractiveness and behavior. Social Influence, 6, 105-112.http://dx.doi.org/10.1080/15534510.2011.561556

Guéguen, N. (2012). "Say it ... near the flow er shop": Further evidence of the effect of flow ers on mating. The Journal of Social Psychology, 152, 529-532. http://dx.doi.org/10.1080/00224545.2012.683463

Guéguen, N., Meineri, S., \& Stefan, J. (2012). "Say it with flowers" ... to female drivers: Hitchhikers holding flowers and driver behavior. North American Journal of Psychology, 14, 623.

Guéguen, N., \& Stefan, J. (2014). "Green altruism”: Short immersion in natural green environments and helping behavior. Environment and Behavior. Advance online publication.

http://dx.doi.org/10.1177/0013916514536576

Hartig, T., Böök, A., Garvill, J., Olsson, T., \& Gärling, T. (1996). Environmental influences on psychological restoration. Scandinavian Journal of Psychology, 37, 378-393. http://dx.doi.org/10.1111/j.1467-9450.1996.tb00670.x

Hartig, T., Evans, G. W., Jamner, L. D., Davis, D. S., \& Gärling, T. (2003). Tracking restoration in natural and urban field settings. Journal of Environmental Psychology, 23, 109-123. http://dx.doi.org/10.1016/S0272-4944(02)00109-3

Hartig, T., Mitchell, R., de Vries, S., \& Frumkin, H. (2014). Nature and health. Annual Review of Public Health, 35, 207-228. http://dx.doi.org/10.1146/annurev-publhealth-032013-182443

Hasbach, P. H. (2012). Ecotherapy. In P. H. Kahan \& P. H. Hasbach (Eds.), Ecopsychology: Science, totems, and the technological species (pp. 115-140). Cambridge, MA: MIT Press.

Haviland-Jones, J., Rosario, H. H., Wilson, P., \& McGuire, T. R. (2005). An environmental approach to positive emotion: Flowers. Evolutionary Psychology, 3, 104-132. http://dx.doi.org/10.1177/147470490500300109

Hinds, J. \& Sparks, P. (2011). The affective quality of human-natural environment relationships. Evolutionary Psychology, 9, 451-469. http://dx.doi.org/10.1177/147470491100900314

How ell, A. J., Dopko, R. L., Passmore, H.-A., \& Buro, K. (2011). Nature connectedness: Associations with well-being and mindfulness. Personality and Individual Differences, 51, 166-171. http://dx.doi.org/10.1016/j.paid.2011.03.037

How ell, A. J., Passmore, H.-A., \& Buro, K. (2013). Meaning in nature: Meaning in life as a mediator of the relationship betw een nature connectedness and well-being. Journal of Happiness Studies, 14, 16811696. http://dx.doi.org/10.1007/s10902-012-9403-x

Huynh, Q., Craig, W., Janssen, I., \& Pickett, W. (2013). Exposure to public natural space as a protective factor for emotional well-being among young people in Canada. BMC Public Health, 13, 407. http://dx.doi.org/10.1186/1471-2458-13-407

Ingulli, K., \& Lindbloom, G. (2013). Connection to nature and psychological resilience. Ecopsychology, 5, 52-55.http://dx.doi.org/10.1089/eco.2012.0042

Intergovernmental Panel on Climate Change (2014). Climate change 2014: Synthesis report. https://www.ipcc.ch/pdf/assessment-report/ar5/syr/SYR AR5 FINAL full.pdf

Joye, Y., \& Bolderdijk, J.-W. (2014). An exploratory study into the effects of extraordinary nat ure on emotions, mood, and prosociality. Frontiers in Psychology, 5, 1577. http://dx.doi.org/10.3389/fpsyg.2014.01577

Kahn, P. H. Jr. (1997). Developmental psychology and the biophilia hypothesis: Children's affiliation with nature. Developmental Review, 17, 1-61.http://dx.doi.org/10.1006/drev.1996.0430

Kahn, P. H. Jr., Severson, R. L., \& Ruckert, J. H. (2009). The human relation with nature and technological nature.Current Directions in Psychological Science, 18, 37-42. http://dx.doi.org/10.1111/j.1467$\underline{8721.2009 .01602 . x}$

Kaplan, S. (2000). New w ays to promote proenvironmental behavior:Human nature and environmentally responsible behavior. Journal of Social Issues, 56, 491-508.

http://dx.doi.org/10.1111/0022-4537.00180 
Kaplan, R., \& Basu, A. (2015). Fostering reasonableness: Supportive environments for bringing out our best. Ann Arbor, MI: Michigan Publishing.

Kaplan, R., \& Kaplan, S. (1989). The experience of nature: A psychological perspective. Cambridge, UK: Cambridge University Press.

Kaplan, S., \& Kaplan, R. (2003). Health, supportive environments, and the Reasonable Person Model. American Journal of Public Health, 93, 1484-1489. http://dx.doi.org/10.2105/AJPH.93.9.1484

Kaplan, S., \& Kaplan, R. (2009). Creating a larger role for environmental psychology: The Reasonable Person Model as an integrative framework. Journal of Environmental Psychology, 29, 329-339. http://dx.doi.org/10.1016/j.jenvp.2008.10.005

Kaplan, S., Kaplan, R., \& Wendt, J. S. (1972). Rated preference and complexity for natural and urban visual material. Perception and Psychophysics, 12, 354-356. http://dx.doi.org/10.3758/BF03207221

Kellert, S. R., \& Wilson, E. O. (1993). The biophilia hypothesis. Washington, DC: Island Press.

Keltner, D., \& Haidt, J. (2003). Approachingawe, a moral, spiritual, and aestheticemotion. Cognition $\mathcal{E}$ Emotion, 17, 297-314.http://dx.doi.org/10.1080/02699930302297

Keyes, C. L. M. (1998). Social well-being. Social Psychology Quarterly, 61, 121-140. http://dx.doi.org/10.2307/2787065

Keyes, C. L. M. (2002). The mental health continuum: From languishing to flourishing in life. Journal of Health and Social Research, 43, 207-222.http://dx.doi.org/10.2307/3090197

Keyes, C. L. M., \& Annas, J. (2009). Feeling good and functioning well: Distinctive concepts in ancient philosophy and contemporary science. Journal of Positive Psychology, 4, 197-201. http://dx.doi.org/10.1080/17439760902844228

Koole, S. L., \& Van den Berg, A. E. (2005). Lost in the wilderness: Terror management, action orientation, and nature evaluation. Journal of Personality and Social Psychology, 88, 1014-1028. http://dx.doi.org/10.1037/0022-3514.88.6.1014

Korpela, K., Borodulin, K., Neuvonen, M., Paronen, O., \& Tyrväinen, L. (2014). Analyzing the mediators between nature-based outdoor recreation and emotional well-being. Journal of Environmental Psychology, 37, 1-7.http://dx.doi.org/10.1016/j.jenvp.2013.11.003

Kuo, F. E. (2003). Social aspects of urban forestry: The role of aboriculture in a healthy social ecology . Journal of Aboriculture, 29, 148-155.

Kuo, F. E., Sullivan, W., Coley, R., \& Brunson, L. (1998). Fertile ground for community: Inner-city neighbourhood of common spaces. American Journal of Community Psychology, 26, 823-851. http://dx.doi.org/10.1023/A:1022294028903

Leary, M. R., Tipsord, J. M., \& Tate, E. B. (2008). Allo-inclusive identity: Incorporating the social and natural worlds into one's sense of self. In H. A. Wayment \& J. J. Bauer (Eds.), Transcending selfinterest: Psychological explorations of the quiet ego (pp. 137-147). Washington, DC: APA.

Louv, R. (2005). Last child in the woods: Saving our children from Nature-Deficit Disorder. Chapel Hill, NC: Algonquin.

Lyubomirsky, S., \& Layous, K. (2013). How do simple positive activities increase well-being? Current Directions in Psychological Science, 22, 57-62. http://dx.doi.org/10.1177/0963721412469809

Maas, J., Verheij, R. A., de Vries, S., Spreeuwenberg, P., Schellevis, F. G., \& Groenewegen, P. P. (2009). Morbidity is related to a green living environment. Journal of Epidemiology and Community Health, 63, 967-973. http://dx.doi.org/10.1136/jech.2008.079038

MacKerron, G., \& Mourato, S. (2013). Happiness is greater in natural environments. Global Environmental Change, 23, 992-1000. http://dx.doi.org/10.1016/j.gloenvcha.2013.03.010

Matz, C. J., Stieb, D. M., Davis, K., Egyed, M., Rose, A., Chou, B., \& Brion, O. (2014). Effects of age, season, gender and urban-rural status on time-activity: Canadian Human Activity Pattern Survey 2 (CHAPS 2). International Journal of Environmental Research and Public Health, 11, 2109-2124. http://dx.doi.org/10.3390/ijerph110202108

Mayer, F. S., \& Frantz, C. M. (2004). The Connectedness to NatureScale: A measure of individuals' feeling in community with nature. Joumal of Environmental Psychology, 24, 504-515.

http://dx.doi.org/10.1016/j.jenvp.2004.10.001 
Mayer, F. S., Frantz, C. M., Bruehlman-Senecal, E., \& Dolliver, K. (2009). Why is naturebeneficial? The role of connectedness to nature. Environment and Behavior, 41, 607-643. http://dx.doi.org/10.1177/0013916508319745

McClean, C. (2015). Forest schools: When every day is a field trip day. Today's Parent. http://ww w .todaysparent.com/family/parenting/forest-schools-when-every-day-is-a-field-trip-day/

McMahan, E. A., \& Estes, D. (2015). The effect of contact with natural environments on positive and negative affect: A meta-analysis. The Journal of Positive Psychology, 10, 507-519. http://dx.doi.org/10.1080/17439760.2014.994224

Mood Walks (2015). Mood Walks for older adults: An Ontario pilot project. http://www.moodwalks.ca/w ordpress/wp-content/uploads/2015/04/CMHA-Mood-WalksEvaluation-Summary.pdf

New ell, P. B. (1997). A cross-cultural examination of favorite places. Environment and Behavior, 29, 495514. http://dx.doi.org/10.1177/001391659702900403

Nisbet, E. K. (2013). David Suzuki Foundation 30x30 Nature Challenge English survey . http://www.davidsuzuki.org/publications/2013/07/23/30x30\%20Nature\%20ChallengeFinal\%20report.pdf

Nisbet, E. K. (2014). Canadians connect with nature and increase their well-being: Results of the 2014 David Suzuki Foundation 30x30 Nature Challenge.

http://ww w .davidsuzuki.org/publications/DSF\%2030x30\%20report.pdf

Nisbet, E. K., \& Zelenski, J. M. (2011). Underestimating nearby nature: Affective forecasting errors obscure the happy path to sustainability. Psychological Science, 22, 1101-1106. http://dx.doi.org/10.1177/0956797611418527

Nisbet, E. K., Zelenski, J. M., \& Murphy, S. A. (2009). The Nature Relatedness Scale: Linking individuals' connection with nature to environmental concern and behavior. Environment and Behavior, 41, 715740. http://dx.doi.org/10.1177/0013916508318748

Nisbet, E. K., Zelenski, J. M., \& Murphy, S. A. (2011). Happiness is in our nature: Exploring nature relatedness as a contributor to subjective well-being. Journal of Happiness Studies, 12, 303-322. http://dx.doi.org/10.1007/s10902-010-9197-7

Norton, C. L., \& Watt, T. T. (2014). Exploring the impact of a wilderness-based positive youth development program for urban youth. Journal of Experiential Education, 37, 335-350. http://dx.doi.org/10.1177/1053825913503113

O'Brien, L., \& Murray, R. (2007). Forest School and its impacts on young children: Case studies in Britain. Urban Forestry \& Urban Greening, 6, 249-265.http://dx.doi.org/10.1016/j.ufug.2007.03.006

O'Connor, K., \& Chamberlain, K. (1996). Dimensions of life meaning: A qualitativeinvestigation at mid life. British Journal of Psychology, 87, 461-477.http://dx.doi.org/10.1111/j.2044-8295.1996.tb02602.x

Passarelli, A., Hall, E., \& Anderson, M. (2010). A strengths-based approach to outdoor and adventure education: Possibilities for personal grow th. Journal of Experiential Education, 33, 120-135. http://dx.doi.org/10.1177/105382591003300203

Passmore, H.-A., \& How ell, A. J. (2014). Nature involvement increases hedonic and eudaimonic wellbeing: A two-w eek experimental study. Ecopsychology, 6, 148-154.

Pergams, O. R. W., \& Zaradic, P. A. (2006). Is love of nature in the U.S. becoming love of electronic media? 16-year downtrend in national park visits explained by w atching movies, playing video games, internet use, and oil prices. Journal of Environmental Management, 80,387-393. http://dx.doi.org/10.1016/j.jenvman.2006.02.001

Pergams, O. R. W., \& Zaradic, P. A. (2008). Evidence for a fundamental and pervasive shift aw ay from nature-based recreation. Proceedings of the National Academy of Sciences, 105,2295-2300. http://dx.doi.org/10.1073/pnas.0709893105

Raihani, N. J., \& Bshary, R. (2012). A positive effect of flowers rather than eye images in a large-scale, cross-cultural dictator game. Proceedings of the Royal Society B: Biological Sciences, 279, 3556-3564. http://dx.doi.org/10.1098/rspb.2012.0758

Ray, H., \& Jakubec, S. L. (2014). Nature-based experiences and health of cancer survivors. Complementary Therapies in Clinical Practice, 20,188-192.http://dx.doi.org/10.1016/j.ctcp.2014.07.005 
Reker, G. T., \& Woo, L. C. (2011). Personal meaning orientations and psychosocial adaptation in older adults. SAGE Open, 1. http://dx.doi.org/10.1177/2158244011405217

Richards, R. (2001). A new aesthetic for environmental aw areness: Chaos theory, the beauty of nature, and our broader humanisticidentity. Journal of Humanistic Psychology, 41, 59-95. http://dx.doi.org/10.1177/0022167801412006

Richardson, M., Hallam, J. \& Lumber, R. (2015). One thousand good things in nature: Aspects of nearby nature associated with improved connection to nature. Environmental Values, 24(5), 603-619. http://dx.doi.org/10.3197/096327115X14384223590131

Rideout, V. J., Foehr, U. G., \& Roberts, D. F. (2010). Generation M²: Media in the lives of 8- to 18-year olds. https://kaiserfamily foundation.files.wordpress.com/2013/04/8010.pdf

Ryan, R. M., \& Frederick, C. (1997). On energy, personality, and health:Subjective vitality as a dynamic reflection of well-being. Journal of Personality, 65, 529-565.http://dx.doi.org/10.1111/j.14676494.1997.tb00326.x

Ryan, R. M., Weinstein, N., Bernstein, J., Brown, K. W., Mistretta, L., \& Gagne, M. (2010). Vitalizing effects of being outdoors and in nature. Journal of Environmental Psychology, 30, 159-168. http://dx.doi.org/10.1016/j.jenvp.2009.10.009

Saraglou, V., Buxant, C., \& Tilquin, J. (2008). Positive emotions as leading to religion and spirituality. Journal of Positive Psychology,3, 165-173.http://dx.doi.org/10.1080/17439760801998737

Schnell, T. (2009). The Sources of Meaning and Meaning in Life Questionnaire(SoMe): Relations to demographics and well-being. The Journal of Positive Psychology, 4, 483-499. http://dx.doi.org/10.1080/17439760903271074

Schultz,P. W. (2001). The structure of environmental concern: Concern for self, other people, and the biosphere. Journal of Environmental Psychology, 21, 327-339.http://dx.doi.org/10.1006/jevp.2001.0227

Selhub, E. M., \& Logan, A. C. (2012). Your brain on nature. Mississauga, ON: John Wiley and Sons Canada, Ltd.

Shiota, M. N., Keltner, D., \& Mossman, A. (2007). The nature of awe: Elicitors, appraisals, and effects on self-concept. Cognition and Emotion, 21, 944-963.http://dx.doi.org/10.1080/02699930600923668

Simonsohn, U., Nelson, L. D., \& Simmons, J. P. (2014). P-curve: A key to the file-drawer. Journal of Experimental Psychology: General, 143,534-547.http://dx.doi.org/10.1037/a0033242

Sommer, R. (2003). Trees and human identity. In S. Clayton \& S. Opotow (Eds.), Identity and the natural environment: The psychological significance of nature (pp. 179-204). Cambridge, MA: MIT Press.

Stefan, J., \& Guéguen, N. (2014). Effect of hair ornamentation on helping. Psychological Reports: Relationships \& Communication, 114, 491-495.http://dx.doi.org/10.2466/21.17.PR0.114k18w8

Steger, M. F., Shim, Y., Rush, B. R., Brueske, L. A., Shin, J. Y., \& Merriman, L. A. (2013). The mind's eye: A photographic method for understanding meaning in people's lives. The Journal of Positive Psychology, 8, 530-542. http://dx.doi.org/10.1080/17439760.2013.830760

Stigsdotter,U. K., Ekholm, O., Schipperijn, J., Toftager, M., Kamper-Jørgensen, F., \& Randrup, T. B. (2010). Health promoting outdoor environments - Associations between green space, and health, health-related quality of life and stress based on a Danish national representative survey. Scandinavian Journal of Public Health, 38, 411-417.http://dx.doi.org/10.1177/1403494810367468

Stillman, J. W., \& Hensley, W. E. (1980). She worea flower in her hair: The effect of ornamentation on nonverbal communication. Journal of Applied Communication Research, 1, 31-39. http://dx.doi.org/10.1080/00909888009360268

Sullivan, W. C., Kuo, F. E., \& Depooter, S. F. (2004). The fruit of urb an nature:Vital neighborhood space. Environment and Behavior, 36, 678-700.http://dx.doi.org/10.1177/0193841X04264945

Tam, K. P. (2013). Concepts and measures related to connection to nature: Similarities and differences. Journal of Environmental Psychology, 34, 64-78.http://dx.doi.org/10.1016/j.jenvp.2013.01.004

Terhaar, T. L. (2009). Evolutionary advantages of intense spiritual experiences in nature. Journal for the Study of Religion, Nature and Culture, 3, 303-339. http://dx.doi.org/10.1558/jsrnc.v3i3.303

The White House, Office of the Press Secretary (2015). Fact sheet: Launching the every kid in a park initiative and designating new national monuments [Press Release]. https://www.whitehouse.gov/the-pressoffice/2015/02/19/fact-sheet-launching-every-kid-park-initiative-and-designating-new-natio 
Thompson-Coon, J., Boddy, K., Stein, K., Whear, R., Barton, J., \& Depledge, M. H. (2011). Does participating in physical activity in outdoor natur al environments have a greater effect on physical and mental wellbeing than physical activity indoors? A systematic review. Environmental Science $\mathcal{E}$ Technology, 45, 1761-1772. http://dx.doi.org/10.1021/es102947t

Tsunetsugu, Y., Park, B. J., \& Miyazaki, Y. (2010). Trends in research related to "Shinrin-yoku” (taking in the forest atmosphere or forest bathing) in Japan. Environmental Health and Preventive Medicine, 15, 2737. http://dx.doi.org/10.1007/s12199-009-0091-z

Ulrich, R. S. (1979). Visual landscapes and psychological well-being. Landscape Research, 4, 17-23. http://dx.doi.org/10.1080/01426397908705892

Ulrich, R. S. (1981). Natural versus urban scenes:Some psychophysiological effects. Environment and Behavior, 13, 523-556. http://dx.doi.org/10.1177/0013916581135001

Ulrich, R. S. (1993). Biophilia, biophobia, and natural landscapes. In S. R. Kellert \& E. O. Wilson (Eds.), The biophilia hypothesis (pp. 73-137). Washington, DC: Island Press.

Ulrich, R. S., Simons, R. F., Losito, B. D., Fiorito, E., Miles, M. A., \& Zelson, M. (1991). Stress recovery during exposure to natural and urban environments. Journal of Environmental Psychology, 11, 201-230. http://dx.doi.org/10.1016/S0272-4944(05)80184-7

United Nations (2014). World urbanization prospects: The 2014 revision. http://esa.un.org/unpd/wup/Highlights/WUP2014-Highlights.pdf

Van den Berg, A. E., Koole, S. L., \& van der Wulp, N. Y. (2003). Environmental preference and restoration:(How) are they related? Journal of Environmental Psychology, 23, 135-146. http://dx.doi.org/10.1016/S0272-4944(02)00111-1

Van den Berg, A. E., Maas, J., Verheij, R. A., \& Groenew egen, P. P. (2010). Green space as a buffer between stressful life events and health. Social Science $\mathcal{E}$ Medicine, 70, 1203-1210. http://dx.doi.org/10.1016/j.socscimed.2010.01.002

Van Herzele, A., \& de Vries, S. (2012). Linking green space to health: A comparative study of two urban neighbourhoods in Ghent, Belgium. Population and Environment: A Journal of Interdisciplinary Studies, 34, 171-193. http://dx.doi.org/10.1007/s11111-011-0153-1

Velarde, M. D., Fry, G., \& Tveit, M. (2007). Health effects of viewing landscapes - Landscape types in environmental psychology. Urban Forestry \& Urban Greening, 6, 199-212. http://dx.doi.org/10.1016/j.ufug.2007.07.001

Vining, J., Merrick, M. S., \& Price, E. A. (2008). The distinction between humans and nature: Human perceptions of connectedness to nature and elements of the natural and unnatural. Human Ecology Review, 15, 1-11.

Weinstein, N., Przybylski, A. K., \& Ryan, R. M. (2009). Can nature make us more caring? Effects of immersion in nature on intrinsic aspirations and generosity. Personality and Social Psychology Bulletin, 35, 1315-1329.http://dx.doi.org/10.1177/0146167209341649

Westwood, R. (2013, June 18). Early education: This is not a field trip. Macleans. http://www.macleans.ca/society/life/this-is-not-a-field-trip/

White, M., Alcock, I., Wheeler, B. W., \& Depledge, M. H. (2013). Would you be happier living in a greener urban area? A fixed-effects analysis of panel data. Psychological Science, 24, 920-928. http://dx.doi.org/10.1177/0956797612464659

White, M., Smith, A., Humphryes, K., Pahl, S., Snelling, D., \& Depledge, M. (2010). Blue space: The importance of water for preference, affect, and restorativeness ratings of natural and built scenes. Journal of Environmental Psychology, 30, 482-493. http://dx.doi.org/10.1016/j.jenvp.2010.04.004

Wilson, E. O. (1984). Biophilia. Cambridge, MA: Harvard University Press.

Wilson, T. D., \& Gilbert, D. T. (2005). Affective forecasting: Knowing what to want.Current Directions in Psychological Science, 14, 131-134.http://dx.doi.org/10.1111/j.0963-7214.2005.00355.x

World Health Organization (2006). Constitution of the World Health Organization. http://www.who.int/governance/eb/who constitution en.pdf

Zelenski, J. M., Dopko, R. L., \& Capaldi, C. A. (2015). Cooperation is in our nature: Nature exposure may promote cooperative and environmentally sustainablebehavior. Journal of Environmental Psychology, 42, 24-31.http://dx.doi.org/10.1016/j.jenvp.2015.01.005 
Zhang, J. W., Piff, P. K., Iyer, R., Koleva, S., \& Keltner, D. (2014). An occasion for unselfing: Beautiful nature leads to prosociality. Journal of Environmental Psychology, 37, 61-72.

http://dx.doi.org/10.1016/j.jenvp.2013.11.008 